\title{
Influence of Thyme and Leek on Immunological Functions and some Haematological parameters in Rats with Cirrhotic Liver
}

Soheir M. El-deab

Afif College of Science and Humanities, Shaqra University, Saudi Arabia

\section{Abstract}

This study aimed to determine the effect of dried thyme and dried leek supplementation on immune functions and some hematological parameters in cirrhotic liver rats. Thirty-six rats weighing $170 \pm 10 \mathrm{~g}$ were used for this purpose. The first main group, a negative control $(n=4)$ fed on the basal diet only. The second main group $(n=32)$ was injected intraperitoneal once with $\mathrm{CCl}_{4}$ at a dose of $0.5 \mathrm{ml} / 100 \mathrm{~g}$ body weight for the first time, after that a dose of $0.3 \mathrm{ml} / 100 \mathrm{~g}$ body weight was injected twice a week for six weeks to induce liver cirrhosis. To ensure that livers become cirrhotic four rats were randomly chosen for pathological examination. The rest of rats $(n=28)$ were divided into (7) subgroups (4 rats each) as follows: Sub G1 (positive control) was fed on basal diet. Sub G (2 and 3) were fed on a basal diet supplemented with $6 \%$ and $12 \%$ dried thyme respectively. Sub G (4 and 5) were supplemented with $6 \%$ and $12 \%$ dried leek respectively. Sub G (6 and 7) were supplemented with $6 \%$ and $12 \%$ of dried (thyme and leek) at a ratio of (1:1) respectively. Rats were fed on the experimental diet for eight weeks. Results protected that the highest (IgG) and (IgM) levels in serum were noticed in the group fed on a combination of dried thyme and dried leek compared to positive control. Diets supplemented with dried thyme, leek and their mixtures at different levels significantly increased $(\mathrm{P}<0.05)$ the levels of serum total protein, globulin and albumin compared to the control positive group. Also, a significant decrease $(\mathrm{P}<0.05)$ in the levels of (AST), (ALP) and (ALT) were noticed in the groups fed on mixture of dried thyme and dried leek. On the other hand, the supplementation with dried thyme, dried leek and their mixtures significantly $(\mathrm{P}<0.05)$ increased the mean level of WBCs, RBCs, PCV and Hemoglobin compared to the positive control. The highest improvment in the tested parameters was observe in the groups fed on a mixture of dried thyme and dried leek at $12 \%$. It can be conclude that supplementation with dried thyme, dried leek, and their combination, could protect the liver cells from CCL4-induced liver damages.The highest improvement was observed in the groups supplemented with, a combination of dried thyme and leek at a ratio of (1:1) respectively.

Key Words: Thyme. Leek. Immunological Functions. Hematological parameters. Liver cirrhosis. 


\section{Introduction}

Liver is one of the most important organs in the biotransformation of food, drugs, endogenous and exogenous substances. Profuse supply of blood and the presence of many redox systems enable liver to convert these substances into different kinds of inactive, active or even toxic metabolites (Wang et al., 2014). The immune system destroys the organisms that cause infection in humans, such as bacteria, fungi, and viruses, Liver fails, may include hypertension, edema, splenomegaly, metabolic bone diseases, and liver cancer. Most important to liver health is a healthy diet and minimal exposure to toxic substances (Barbalho et al, 2009). Medicinal plants were used as the only form of health care readily available to the majority of human populations for centuries. (Bernaert et al., 2012 \& Hasona et al., 2017). Supplementation with particular herbs and nutrients can also help protect and support healthy liver function and stimulate internal detoxification. (Oliveira et al., 2014). Dietary polyphenols have been shown to inhibit LDL oxidation, scavenge superoxide, and increase antioxidant capacity (Khaksar et al., 2012 \& Otunola, et al., 2014).

Thyme (Thymus vulgaris), due to its richness in essential oils and phenolic compounds together with other constituents, has attracted the investigators in the field of medicinal plants. In this regard, the crude extract of the plant and/or isolated compounds have shown immune modulators (El-Ghousein, and AlBeitawi 2009) anti-mutagenic and anti-oxidant effects (Grigore et al., 2010). All parts of the thyme have culinary and medicinal value, thyme's active ingredients are found in both roots and leaves. thyme is a rich source of vitamins and minerals. Leek (allium ampeloprasum) has a long history of use as an immune system booster because of its anti-fungal, antiseptic, and nutritive properties. (Bernaert et al., 2013). Leeks are nutrient-dense, meaning that they're low in calories yet high in vitamins and minerals. Leeks are a rich source of antioxidants, particularly polyphenols and sulfur compounds. Antioxidants fight oxidation, which damages your cells and contributes to illnesses like diabetes, cancer, and heart disease. Leeks are a particularly great source of kaempferol, a polyphenol antioxidant thought to protect against heart disease and some types of cancer. This study aimed to investigate the effect of dried thyme and dried garlic supplementation on Immunological Functions and some Hematological parameters in Rats with Cirrhotic Liver. 


\section{Materials and Methods}

\subsection{Materials}

2.1.1. Chemicals: Casein, cellulose, Vitamins, minerals and Carbon tetrachloride (CCl4), were purchased from El-Gomhoria Company, Cairo, Egypt. Kits for blood analysis were obtained from Gama Trade Company, Cairo, Egypt.

2.1.2. Plants: Fresh Thyme (Thymus vulgaris) and Leek (allium ampeloprasum) were purchased from the Agriculture Research Center, Giza, Egypt.

2.1.3. Animals: Rats were obtained from animal house of the Ophthalmology Research Center in Giza, Egypt. conditions approved by the Ethics Committee of Ophthalmology Research Center Giza, Egypt, of Experimental Animals, which conformed to the international ethics for handling and care of experimental animals according to Canadian Council on Animal Care (1993).

\subsection{Methods:}

2.2.1. Preparation of dried thyme and leek: fresh thyme and leek were cleaned, washed, dried by solar energy at $50^{\circ} \mathrm{C}$ at the National Research Center, Dokki, Egypt, and were well grinded to get the fine powder. The crude chemical composition of dried thyme and leek as moisture, protein, fats, vitamins and ash were estimated in accordance with (A.O.A.C. 2005) whereas carbohydrates were calculated by deduction. Minerals content including zinc $(\mathrm{Zn})$, iron $(\mathrm{Fe})$, sodium $(\mathrm{Na})$, manganese $(\mathrm{Mn})$, magnesium $(\mathrm{Mg})$, cupper $(\mathrm{Cu})$ and calcium $(\mathrm{Ca})$ were determined according to (Chapman \& Pratt, 1978).

\subsubsection{Experimental animals:}

Adults male albino rats $(n=36)$ of Sprague- Dawely Strain weighing $(170 \pm 10$ g) were housed in well-aerated cages and fed on a basal diet for one week for adaptation according to Canadian Council on Animal Care (1993). Basal diet was formulated according to (Reeves et al., 1993). Rats were divided to (2) main groups as follows:

The first main group. Negative control group $(n=4)$ was fed on the basal diet during the all experimental period.

The second main group $(\mathrm{n}=32)$ was injected was injected with $\mathrm{CCl} 4$ intraperitoneal with $\mathrm{CCl}_{4}$ at a dose of $0.5 \mathrm{ml} / 100 \mathrm{~g}$ body weight for the first time and after one week at a dose of $0.3 \mathrm{ml} / 100 \mathrm{~g}$ body weight twice a week for six weeks to induce liver cirrhosis (Zhao et al., 2014). To ensure that livers become cirrhotic from the injected rats $(n=4)$ were chosen randomly and slain 
and the liver was subjected to pathological examination. Rats with liver cirrhosis $(n=28)$ were divided into 7 subgroups ( 4 rats each) as follows:

Subgroup (1): positive control group was fed on basal diet.

Subgroups (2 and 3) Rats with liver cirrhosis fed on a basal diet supplemented with $6 \%$ and $12 \%$ thyme respectively.

Subgroups (4 and 5) Rats with liver cirrhosis were fed on a basal diet supplemented with $6 \%$ and $12 \%$ leek respectively.

Subgroups (6 and 7) Rats with liver cirrhosis were fed on a basal diet supplemented with $6 \%$ and $12 \%$ of (thyme and leek) at a ratio of $(1: 1)$ respectively. At the end of the experimental period ( 7 weeks), Rats were fasted for 12 hours, and sacrificed under ether anesthesia. Sampling Blood from the Lateral Tail Vein of the rat were collected from each rat, blood samples the follow, the first sample of blood was collected into a centrifuge tube, and was centrifuged for 15 minutes at 3000 r.p.m. to obtain serum. .Serum was stored at$20^{\circ} \mathrm{C}$ to used for subsequent analysis. The second blood sample was collected, into a tube containing EDTA for the assessment of hematological indices.

\subsection{Biochemical analysis:}

Immunoglobulin $\mathrm{G}$ (IgG) and Immunoglobulin $\mathrm{M}$ (IgM) were measured according to (Ziva and Pannall, 1984). Alanine aminotransferase (ALT) and aminotransferase (AST) were determined by the method of (Reitman and Frankel, 1957) and alkaline phosphatase (ALP) according to the method of (Roy, 1970). Red blood cell (RBC) count, total leucocytes count(WBC), hemoglobin concentrations were estimated, and packed cell volume (PCV) was determined by using the standard hematological technique witch described by (Ochei and Kolharktar 2008). Total protein, globulin, and albumin were estimated by the method of (Weissman et al., 1995). Total cholesterol (TC) and triglycerides (TG) according to (Artimage and Berry, 1987). High-density lipoprotein (HDL-C) was determined as the method of (Albers et al ., 1983). While, low-density lipoprotein (LDL-C) and Very-low-density lipoprotein (VLDL-C) were calculated according to (Fridewald et al.,1972).

\subsection{Statistical analysis:}

Results were expressed as means \pm Standard Error (SE).The obtained results were analyzed according to SPSS program, version (18). ANOVA test was used for compare results between groups ( $\mathrm{p}$-value was considered to be significant at $\mathrm{P} \leq$ 0.05) was considered to be significant (Richmond, 1973). 


\section{Results.}

Table (1): The crude chemical composition of dried thyme and leek.

\begin{tabular}{l|l|c|c}
\hline & \multicolumn{1}{|c|}{ Nutrients $(/ 100 \mathrm{~g})$} & thyme & leek \\
\hline \multirow{4}{*}{$\begin{array}{l}\text { Macro } \\
\text { nutrients }\end{array}$} & Calories $(\mathrm{k} . c \mathrm{cal})$ & 330 & 206 \\
\cline { 2 - 4 } & Proteins $(\mathrm{g})$ & 4.7 & 8.8 \\
\cline { 2 - 4 } & Fats $(\mathrm{g})$ & 16 & 0.8 \\
\cline { 2 - 4 } & omega-3 $(\mathrm{g})$ & 1.2 & 27.4 \\
\cline { 2 - 4 } & omega-6(g) & 1.3 & 310 \\
\cline { 2 - 4 } & Carbohydate $(\mathrm{g})$ & 68 & 44 \\
\cline { 2 - 4 } & Total fiber $(\mathrm{g})$ & 46 & 2.8 \\
\hline \multirow{3}{*}{ Vitamins } & Vitamin A (IU) & 311 & 12.1 \\
\cline { 2 - 4 } & Vitamin C (mg) & 63 & 42.3 \\
\hline
\end{tabular}

The chemical composition of dried thyme and dried leek was shown in Table (1) dried thyme is high in (carbohydrates, calories, total fiber, total fat, vitamin $\mathrm{C}$, and vitamin A) while low in, protein. Regarding to dried Leek is very low in carbohydrates, vitamin C, calories, and, vitamin A. But it is higher than thyme in omega-3, omega-6 fatty acids and, total fat.

Table (2): Effect of dried thyme and leek supplementation on serum IgM and $\mathrm{IgG}$ in rats with cirrhotic liver.

\begin{tabular}{l|l|l}
\hline \multicolumn{1}{|c|}{ Parameters } & IgG $(\mathrm{mg} / \mathrm{ml})$ & $\operatorname{IgM}(\mathrm{mg} / \mathrm{ml})$ \\
\hline Control (-ve) & $5.30 \pm 0.20^{\mathrm{a}}$ & $3.90 \pm 0.04^{\mathrm{a}}$ \\
\hline Control (+ve) & $1.33 \pm 0.06^{\mathrm{g}}$ & $0.48 \pm 0.09^{\mathrm{f}}$ \\
\hline Thyme 6\% & $2.23 \pm 0.14^{\mathrm{f}}$ & $1.09 \pm 0.05^{\mathrm{e}}$ \\
\hline Thyme 12\% & $2.99 \pm 0.15^{\mathrm{e}}$ & $1.23 \pm 0.06^{\mathrm{e}}$ \\
\hline Leek 6\% & $3.71 \pm 0.06^{\mathrm{d}}$ & $1.93 \pm 0.07^{\mathrm{d}}$ \\
\hline Leek 12\% & $3.91 \pm 0.20^{\mathrm{d}}$ & $2.02 \pm 0.05^{\mathrm{d}}$ \\
\hline Combination 6\% (1:1) & $4.27 \pm 0.19^{\mathrm{c}}$ & $2.77 \pm 0.18^{\mathrm{c}}$ \\
\hline Combination 12\% (1:1) & $4.89 \pm 0.15^{\mathrm{b}}$ & $3.40 \pm 0.20^{\mathrm{b}}$ \\
\hline
\end{tabular}

Values in the same column sharing the same superscript letters are not significantly different at $P<0.05$

Values were expressed as Means $\pm \mathrm{SE}$. 
Table (2) illustrates the effect of dried thyme and leek at different levels on serum immunoglobulins ( $\operatorname{IgM}$ and $\operatorname{IgG}$ ) in rats with cirrhotic liver. The injection with $\mathrm{CCl}_{4}$ induced deficiency in immunity system in rats. There are significant decrease $(\mathrm{P}<0.05)$ in the mean value of $\operatorname{IgM}$ and $\operatorname{IgG}$ compared to the negative control group. Diets fortified with different levels of dried thyme or dried leek showed a significant increase $(\mathrm{P}<0.05)$ in the mean levels of $\operatorname{IgG}$ and IgM, respectively comparing with the positive control group. Also noted a significant difference $(\mathrm{P}<0.05)$ in the level of $\operatorname{IgG}$ and IgM between the groups that fed on the different levels of thyme, leek, and a mixture of thyme and leek. The highest IgG and IgM level were observed in groups fed on a mixture of dried (thyme and leek).

Table (3): Effect of dried thyme and leek supplementation on serum total protein, albumin and globulin in rats with cirrhotic liver.

\begin{tabular}{|c|c|c|c|}
\hline \multirow{2}{*}{$\begin{array}{ll} & \text { Parameters } \\
\text { Groups } & \end{array}$} & Total protein & Albumin & Globulin \\
\hline & \multicolumn{3}{|c|}{$(\mathrm{g} / \mathrm{dl})$} \\
\hline Control (-ve) & $12.23 \pm 0.15^{\mathrm{a}}$ & $6.12 \pm 0.18^{\mathrm{a}}$ & $6.93 \pm 0.09^{\mathrm{a}}$ \\
\hline Control (+ve) & $4.81 \pm 0.37^{\mathrm{f}}$ & $2.15 \pm 0.10^{f}$ & $1.26 \pm 0.27^{\mathrm{g}}$ \\
\hline Thyme $6 \%$ & $6.76 \pm 0.39^{\mathrm{e}}$ & $2.96 \pm 0.14^{\mathrm{e}}$ & $2.71 \pm 0.33^{f}$ \\
\hline Thyme $12 \%$ & $8.05 \pm 0.53^{d}$ & $3.78 \pm 0.11^{\mathrm{d}}$ & $3.58 \pm 0.24^{\mathrm{e}}$ \\
\hline Leek 6\% & $8.59 \pm 0.28^{\mathrm{cd}}$ & $3.94 \pm 0.19^{d}$ & $4.41 \pm 0.27^{\mathrm{d}}$ \\
\hline Leek $12 \%$ & $9.16 \pm 0.08^{c}$ & $4.16 \pm 0.10^{\mathrm{d}}$ & $5.52 \pm 0.09^{c}$ \\
\hline Combination $6 \%(1: 1)$ & $10.68 \pm 0.27^{b}$ & $4.79 \pm 0.23^{\mathrm{c}}$ & $5.94 \pm 0.07^{\mathrm{bc}}$ \\
\hline Combination $12 \%(1: 1)$ & $11.31 \pm 0.19^{b}$ & $5.65 \pm 0.19^{b}$ & $6.37 \pm 0.23^{b}$ \\
\hline
\end{tabular}

Values in the same column sharing the same superscript letters are not significantly different at $P<0.05$ Values were expressed as Means $\pm \mathrm{SE}$.

Table (3) shows the effect of dried thyme and leek at different levels on serum protein parameters (total protein, globulin, and albumin) in rats with cirrhotic liver. Diets fortified with dried thyme or dried leek or their mixture at different levels significantly increased $(\mathrm{P}<0.05)$ the mean levels of globulin, albumin and total protein, respectively. The highest increase in protein parameters was observed in the groups supplemented with a mixture of dried thyme and dried leek. 
Table (4): Effect of dried thyme and leek supplementation on Liver function enzymes in rats with cirrhotic liver

\begin{tabular}{l|l|l|l}
\hline \multicolumn{1}{c|}{ Parameters } & AST $(\mu / \mathrm{L})$ & $\operatorname{ALT}(\mu / \mathrm{L})$ & ALP $(\mu / \mathrm{L})$ \\
\hline Control (-ve) & $70.62 \pm 3.58^{\mathrm{g}}$ & $24.09 \pm 2.06^{\mathrm{e}}$ & $152.74 \pm 3.09^{\mathrm{f}}$ \\
\hline Control (+ve) & $143.46 \pm 3.15^{\mathrm{a}}$ & $57.22 \pm 1.67^{\mathrm{a}}$ & $284.56 \pm 1.61^{\mathrm{a}}$ \\
\hline Thyme 6\% & $131.64 \pm 3.18^{\mathrm{b}}$ & $51.18 \pm 1.17^{\mathrm{b}}$ & $239.73 \pm 8.36^{\mathrm{b}}$ \\
\hline Thyme 12\% & $124.28 \pm 2.46^{\mathrm{bc}}$ & $47.44 \pm 1.16^{\mathrm{b}}$ & $222.64 \pm 3.37^{\mathrm{c}}$ \\
\hline Leek 6\% & $118.50 \pm 2.25^{\mathrm{cd}}$ & $41.66 \pm 2.28^{\mathrm{c}}$ & $227.20 \pm 5.60^{\mathrm{bc}}$ \\
\hline Leek 12\% & $111.05 \pm 2.31^{\mathrm{d}}$ & $39.68 \pm 0.89^{\mathrm{c}}$ & $219.23 \pm 1.36^{\mathrm{c}}$ \\
\hline Combination 6\% (1:1) & $97.59 \pm 1.08^{\mathrm{e}}$ & $34.32 \pm 0.82^{\mathrm{d}}$ & $187.02 \pm 3.42^{\mathrm{d}}$ \\
\hline Combination 12\% (1:1) & $86.76 \pm 2.44^{\mathrm{f}}$ & $28.11 \pm 1.04^{\mathrm{e}}$ & $171.21 \pm 2.31^{\mathrm{e}}$ \\
\hline
\end{tabular}

Values in the same column sharing the same superscript letters are not significantly different at $\mathbf{P}<0.05$

Values were expressed as Means $\pm \mathrm{SE}$.

(AST): aminotransferase

(ALT): Alanine aminotransferase

(ALP): alkaline phosphatase

$(\mu / \mathrm{L})$ : micro per liter

Results in the table (4) showed the effect of dried thyme and leek at different levels on Liver function enzymes in Cirrhotic Liver. Rats injected with $\mathrm{CCl} 4$ (positive control rats) had significant increase $(\mathrm{P}<0.05)$ in the mean value of serum AST,ALT and ALP compared to the negative control group. Supplementation with different levels of dried thyme and leek, significantly decreased $(\mathrm{P}<0.05)$ the mean level of liver enzymes compared with the positive control group. Results illustrate a significant differences $(\mathrm{P}<0.05)$ in the level of serum ALT and AST among the groups fed on a diet fortified with dried thyme and dried leek compared with the positive control group. Supplementation with a mixture of dried thyme and dried leek showed the highest decrease $(\mathrm{P}<0.05)$ in the levels of ALT, AST, and ALP respectively compared to the positive control group. 
Table (5): Effect of dried thyme and leek supplementation on serum lipids profile in rats with cirrhotic liver

\begin{tabular}{|c|c|c|c|c|c|}
\hline \multirow[t]{2}{*}{ Parameters } & TC & TG & HDL-C & LDL-C & VLDL-C \\
\hline & \multicolumn{5}{|l|}{$\mathrm{mg} / \mathrm{dl}$} \\
\hline Control (-ve) & $78.90 \pm 2.97^{d}$ & $44.31 \pm 2.17^{\mathrm{e}}$ & $61.18 \pm 2.26^{\mathrm{a}}$ & $11.52 \pm 0.76^{\mathrm{e}}$ & $10.03 \pm 0.41^{\mathrm{e}}$ \\
\hline Control (+ve) & $117.18 \pm 3.59^{\mathrm{a}}$ & $89.01 \pm 4.03^{\mathrm{a}}$ & $35.39 \pm 2.42^{\mathrm{e}}$ & $62.32 \pm 1.16^{\mathrm{a}}$ & $17.69 \pm 0.78^{\mathrm{a}}$ \\
\hline Thyme $6 \%$ & $105.69 \pm 2.34^{b}$ & $78.40 \pm 0.59^{b}$ & $42.03 \pm 1.51^{\mathrm{d}}$ & $45.03 \pm 1.14^{\mathrm{b}}$ & $15.98 \pm 0.13^{b}$ \\
\hline Thyme $12 \%$ & $96.73 \pm 1.73^{\mathrm{c}}$ & $67.68 \pm 0.86^{c}$ & $45.11 \pm 2.07^{\mathrm{cd}}$ & $36.59 \pm 3.31^{c}$ & $13.87 \pm 0.19^{\mathrm{c}}$ \\
\hline Leek 6\% & $93.77 \pm 2.78^{c}$ & $65.10 \pm 2.09^{c}$ & $47.44 \pm 0.91^{\mathrm{cd}}$ & $30.55 \pm 1.68^{d}$ & $13.10 \pm 0.55^{\mathrm{c}}$ \\
\hline Leek $12 \%$ & $91.15 \pm 1.83^{c}$ & $62.23 \pm 1.14^{\mathrm{c}}$ & $51.00 \pm 1.21^{b c}$ & $24.77 \pm 2.36^{d}$ & $12.56 \pm 0.20^{\mathrm{c}}$ \\
\hline Combination $6 \%(1: 1)$ & $77.25 \pm 1.74^{d}$ & $56.02 \pm 1.50^{d}$ & $55.31 \pm 3.14^{\mathrm{ab}}$ & $9.12 \pm 3.19^{\mathrm{ef}}$ & $11.39 \pm 0.31^{\mathrm{d}}$ \\
\hline Combination $12 \%(1: 1)$ & $74.82 \pm 1.76^{\mathrm{d}}$ & $54.35 \pm 1.81^{\mathrm{d}}$ & $58.26 \pm 1.65^{\mathrm{a}}$ & $5.00 \pm 0.53^{\mathrm{f}}$ & $11.10 \pm 0.26^{\mathrm{d}}$ \\
\hline \multicolumn{6}{|c|}{ Values in the same column sharing the same superscript letters are not significantly different at $\mathbf{P}<\mathbf{0 . 0 5}$} \\
\hline \multicolumn{6}{|c|}{ Values were expressed as Means $\pm \mathrm{SE}$. } \\
\hline \multicolumn{6}{|l|}{ TC:-Total cholesterol } \\
\hline \multicolumn{6}{|l|}{ TG:-Triglycerides } \\
\hline \multicolumn{6}{|l|}{ HDL:-High-density lipoprotein } \\
\hline \multicolumn{6}{|l|}{ LDL-C:-Low-density lipoproteins } \\
\hline \multicolumn{6}{|c|}{ VLDL-C:-Very low-density lipoproteins } \\
\hline
\end{tabular}

Table (5) revealed the effect of dried thyme and leek at different levels on TG, TC, HDL, LDL and, VLDL, in cirrhosis rats. Diets supplemented with dried thyme or dried leek at different levels showed a significant decrease $(\mathrm{P}<0.05)$ in the mean levels of TG, TC, LDL and VLDL compared to the positive control group while serum HLD-c was significantly increased $(\mathrm{P}<0.05)$. Diets supplemented with dried leek or a combination of dried thyme and dried leek showed a significant decrease $(\mathrm{P}<0.05)$ in the levels of $\mathrm{TG}, \mathrm{TC}$, LDL and VLDL compared to the control positive group, an increase in the level of HDL-c was observed. It was noted that the more improvement in lipid profile has observed in the groups fed on a combination of dried thyme and dried leek. 
Table (6): Effect of dried thyme and dried leek supplementation on blood cell parameters in rats with cirrhotic liver.

\begin{tabular}{l|l|l|l|l}
\hline $\begin{array}{l}\text { Groups } \\
\text { Parameters }\end{array}$ & $\begin{array}{l}\text { Hemoglobin } \\
\%\end{array}$ & $\begin{array}{l}\text { RBCs } \\
\text { (million/c.mm }\end{array}$ & $\begin{array}{l}\text { WBCs(thousands } \\
\text { /c.mm) }\end{array}$ & PCV\% \\
\hline Control (-ve) & $16.80 \pm 0.13^{\mathrm{a}}$ & $7.43 \pm 0.25^{\mathrm{a}}$ & $3.59 \pm 0.18^{\mathrm{c}}$ & $64.33 \pm 2.06^{\mathrm{a}}$ \\
\hline Control (+ve) & $8.12 \pm 0.42^{\mathrm{f}}$ & $2.35 \pm 0.40^{\mathrm{d}}$ & $11.61 \pm 0.96^{\mathrm{a}}$ & $25.98 \pm 5.04^{\mathrm{d}}$ \\
\hline Thyme 6\% & $11.98 \pm 0.24^{\mathrm{e}}$ & $4.24 \pm 0.04^{\mathrm{c}}$ & $6.20 \pm 0.69^{\mathrm{b}}$ & $39.47 \pm 1.53^{\mathrm{b}}$ \\
\hline Thyme 12\% & $12.20 \pm 0.21^{\mathrm{d}}$ & $4.67 \pm 0.09^{\mathrm{c}}$ & $6.64 \pm 0.28^{\mathrm{b}}$ & $44.00 \pm 2.02^{\mathrm{b}}$ \\
\hline Leek 6\% & $12.99 \pm 0.10^{\mathrm{cd}}$ & $4.51 \pm 0.07^{\mathrm{c}}$ & $6.49 \pm 0.45^{\mathrm{b}}$ & $38.49 \pm 0.54^{\mathrm{b}}$ \\
\hline Leek 12\% & $13.79 \pm 0.22^{\mathrm{bc}}$ & $4.97 \pm 0.32^{\mathrm{c}}$ & $7.19 \pm 0.04^{\mathrm{b}}$ & $43.00 \pm 2.01^{\mathrm{b}}$ \\
\hline Combination 6\% & $14.13 \pm 0.14^{\mathrm{b}}$ & $5.80 \pm 0.16^{\mathrm{b}}$ & $4.68 \pm 0.16^{\mathrm{c}}$ & $52.44 \pm 1.58^{\mathrm{b}}$ \\
\hline Combination 12\% & $14.65 \pm 0.48^{\mathrm{b}}$ & $6.21 \pm 0.19^{\mathrm{b}}$ & $4.00 \pm 0.07^{\mathrm{c}}$ & $59.60 \pm 2.02^{\mathrm{ab}}$ \\
\hline
\end{tabular}

Values in the same column sharing the same superscript letters are not significantly different at $\mathbf{P}<0.05$

Values were expressed as Means $\pm \mathrm{SE}$.

Table (6) shows the effect of dried thyme and dried leek at different levels on Hemoglobin and blood cell parameters of cirrhosis rats. Fortification with dried thyme, dried leek, and their combination significantly $(\mathrm{P}<0.05)$ increased the mean level of WBCs, PCV, RBCs, and Hemoglobin. The highest increase has observed at the groups fed on a combination of thyme and leek.

\section{Discussion}

In the existing results, $\mathrm{CCl} 4$ induced liver cirrhosis and increasing AST, ALT, and ALP activities. Dietary supplement because of its powerful antioxidant activity may function as an immunoenhancing antioxidant that could help alleviate the oxidative stress condition and will probably be effective in some stressed condition such as protein or antioxidant deficiency (Hasona et al., 2017). However, a mixture of dried thyme and leek management effectively enhanced the elevated enzyme activities of the above-mentioned parameters. These observations are in agreement with other studies ( Hasona and Morsi., 2018) which declared that any harm in the liver can weaken its functions and cause numerous implications on human health. The obtained results showed that supplementation with dried thyme increased the immune functions may be due to its contained of phenolic compounds this results in agree with (Khaksar et al., 2012) who mentioned that thyme contained the highest concentration of phenolic substances obtained from the leaves of the evergreen shrub thyme. The 
phenolic compounds responsible for thyme antioxidant activity are mainly phenolic diterpenes such as carnosol, carnosic acid, epirosmanol and thymol were a potent antioxidant having inhibition effect of superoxide anion production, as well as lipid peroxidation and free radical scavenging activities (Grigore et al., 2010). The current results are in agreement with (Saleh, et al., 2014) who illustrated that the administration thyme extract by rats alleviated the deleterious effect of $\mathrm{CCl}_{4}$ on the liver. Also in agree with (Popović et al., 2016) who mentioned that Thyme may act as a co-factor in the synthesis of biological endogenous antioxidant material. In the current study, high doses induced a high degree of improvement and protection; this could be attributed to the high doses contain on the high percentage of antioxidants. The continuous administration of thyme extract besides $\mathrm{CCl}_{4}$ built a continuous resistant-barrier with more protection battery against oxidative radicals (Higgs et al., 2014). Primary Pharmacological effects of thyme arise from thymol and carvacrol, which are the most important bioactive compounds that this plant contains. (Nasir and Sabah. 2012 \& Oliveira et al., 2014). The current results agree with (ElGhousein, and Al-Beitawi, 2009\& Wang et al., 2014) who found that Thyme reduced the $\mathrm{CCl}_{4}$-induced hepatotoxicity in rats possibly by blocking the formation of free radicals generated during $\mathrm{CCl}_{4}$ metabolism. Recently, leek has been suggested as a promising candidate for maintaining the homeostasis of the immune system (Nasir and Sabah 2012). Leek also contains a high concentration of selenium, which is responsible, part, for leek's antioxidant and cancer- preventive effects. Hence, some growers add selenium to the soil to increase leek's selenium content (Bernaert et al., 2013 and Zhao et al., 2014). Leek has a long history of use as an immune system booster due to its nutritive properties, anti-fungal and antiseptic. It is contain of a natural DE toxicant without any side effects.

\section{Conclusions}

It can be conclude that supplementation with dried thyme, leek, and their combination, could protect the liver cells from CCL4-induced liver damages. The highest improvement in the tested parameters has recorded in the groups supplemented with, a combination of thyme and leek. 


\section{References}

Albers, R. S.; Benderson, V. and warnick, G. (1983):

Enzmatic determination of high density lipoprotein cholesterol,

Selected Methods,Clin. Chem,10 (23):91-99.

AOAC (2005):

Official methods for analysis of the association of official analytical chemist. A. O.A.C., 12th Ed. Washington, D.

Artimage, G.Y.; and Berry, W. G. (1987):

Statistical Methods 7thEd.Ames, lowa State University Press,39-63.

Barbalho, S.M. ; Machada Spada, A.P. ; Prado de Oliveira, E. ; PaivaFilho, M.E. ; Martuchi, K.A. ; Coelho Leite, N. ; Deus, R.M. ; Sasaki,V. ; Silva Braganti, L. and Oshiiwa, M. (2009):

Mentha piperita effect on wister rat plasma lipids. Braz. Arch. Biol. Techn. 52:1137-1143.

Bernaert, N. Krifenberg, U. Larsent, S. and Mruenwald, J. (2012):

Antioxidant capacity, ascorbate content and total phenolic as a function of the genetic diversity of leek. Food Chem, 133:495-511.

Bernaert, N. Van Bockstaele, E. Wouters, D. De Vuyst, L. Van

Droogenbroeck, B. De Clercq, H. and De Loose, M. ( 2013):

Antioxidant changes of the white shaft and green leaves. J Sci Food Agric, 93:2146-2153.

Canadian Council on Animal Care "CCAC" (1993):

Guide to the care and use of experimental animals, Ottawa Ontario Canada 1-298

Chapman, H. and Pratt, P. (1978):

Methods of analysis from soils, plant and water.Univ. of California. Div. Agric. Sci., pp: 50.

El-Ghousein, S.S. ; and Al-Beitawi, N.A. (2009):

The effect of feeding of crushed Thyme on growth,.J. Poultry Sci. 46:100-104.

Fridewald, W.T.; Leve, R.I. ; and Fredrickson, D.S.(1972):

Estimation of the concentration of low density lipoprotein.Clin. Chem., 18:499-502.

Grigore, A. Colceru-Mihul, S. Paraschiv, I. A. and Draghici E,Ichim, M. (2010). Chemical composition and antioxidant activity of Thymus vulgaris L. Romanian Biotechnological Letters. 15(4):5436-5443. 
Hasona, N.A.; Alghassab, T.A.; Ahmed, M.Q.; and Alghabban, A.A. (2017): Ameliorative properties of Iranian Trigonella foenumgraecum seeds. Asian Pac J Trop Biomed. 7(3):234-239.

Hasona, N. and Morsi, A. (2018):

Grape seed extract alleviates dexamethasoneinduced

hyperlipidemia, hematological alteration, and lipid peroxidation in rats. Ind. J. Clin. Biochem. 34(2):213-218.

Higgs, P. Chouteau, T. and Lerat, H. (2014):

Liver let die: oxidativeDNA damage and hepatotropic viruses," Journal of GeneralVirology, 95(5):991-1004.

Khaksar ,V.Krimpen, M.V. ; Hashemipour, H. and Pilevar, M. (2012): Effects of thyme essential oil on performance, some blood parameters and ileal microflora of Japanese quail. The Journal of Poultry Science; 49(2):106-110.

Nasir,N. and Sabah, A. (2012):

Hepatoprotective and some haematological parameters eàect of Allium ampeloprasum against carbon.tetrachloride induced liver toxicity in albino rats. Kufa Journal for Veterinary Medical Sciences‘Vol. 3(2):117-126

Ochei, J. and Kolhatkar, A. (2008):

Medical Laboratory Sciences; Theory and Practice. Tata McGrawHill Publishing Co. Ltd. New Delhi; 321-324.

Oliveira, D. A. Santos, S. Barbosa,D. F. and Silva, C. A. (2014):

Mandarim-de-Lacerda, and M. B. Aguila, "inflammatory and liver damage of a sucrose-rich diet in mice," Journal of Nutritional Biochemistry, vol. 25(2): 193-200.

Otunola, O. B. Oloyede, A. T. Oladiji, and A. J. and Afolayan, R. (2014): Selected spices and their combination modulate hypercholesterolemia-induced oxidative stress in experimental rats," Biological Research, vol. 47(1): 1. 5.

Popović, S. Puvača, N. Kostadinović, L. Džinić, N. Bošnjak, J.and Vasiljević, M. (2016):

Effects of dietary essential oils on productive performance, blood lipid, enzyme activity and immunological response of broilerchickens. European Poultry Science;80:1-12

Reeves, R.G.; Nielsen, F.H. ; and Fahey, G.C.(1993):

AIN-93 Purified Diets for Labortory Rodents. J.Nutr., 123(1):19391951. 
Reitman, S. and Franke, l. (1957):

A colorimetric method for the determination of serum glutamic oxaloacetic and glutamic pyruvic transaminases. Am. J. Clin. Pathol. 28, 56-63.

Richmond, N.(1973):

Statistical Methods 7thEd.Ames, lowa State University Press, 39-63.

Roy, S.E. (1970):

Colorimetric determination of serum alkaline phosphatase. Clin Chem;16: 431- 432.

Saleh, N. El-latif, A.A. ; Ghazy, E. and Allam, T. (2014):

The effects of dietary supplementationof different levels of thyme and ginger essential oils on performance, hematological, and immunological parameters of broiler chickens. Global Veterinaria.12(6):736-744.

SPSS (2011):

Statistical packages for the social sciences. 20th ed. Chicago: IBM.

Wang, H. P.; Wang, M. Y.; and Xu, U. (2014):

Combined subchronic toxicity of dichlorvos with malathion," Food and Chemica Toxicology, vol. 70, pp. 222-230.

Weissman, N.; Schoenbach, E.B. and Armestead, E.B. (1995):

J.biol. chem., 187:153.Cited in the Panphlet of Stanbio Laboratory, Boerne, Texas, USA.

Zhao, Y.; Ma X.; Wang J.; He X.; Hu Y.; Zhang P.; Wang R.; Li

R.; Gong M.; Luo S. and Xiao X. (2014):

Curcumin Protects against CCl4-Induced Liver Fibrosis by Inhibiting HIF-1 $\alpha$., Molecules; 19: 18767-18780.

Ziva, J. and Pannall, P. (1984):

Clinical chemistry in diagnosis and treatment. Publ. Lloyd-Luke (Medical books), PP:348-352. 


\section{ملخص البحث}

تأثير الزعتر والكراث على الوظائف المناعية ويعض قياسات الام علي الفئران المصابة بالتليف الكبدي

أجريت هذه الدراسة لمعرفة تأثير الزعتر والكراث على الوظائف المناعية وبعض قياسات الدم في الفئران المصابة بالتليف الكبدي، تم استخدام (דب) فأر وقسمت المجموعات كالتالي المجموعة الاولي الرئيسية وهي المجموعة الضابطة السالبة (ع فئران) وتتغذي على الغذاء الاساسي فقط. المجموعة الثانية الرئيسية

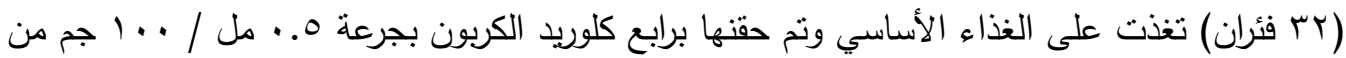

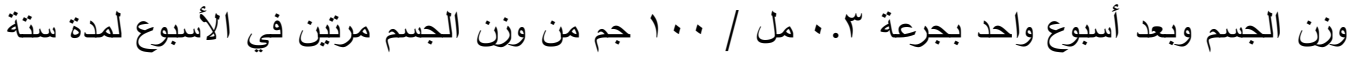

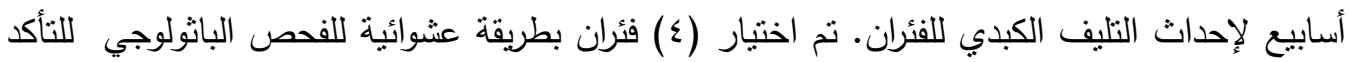

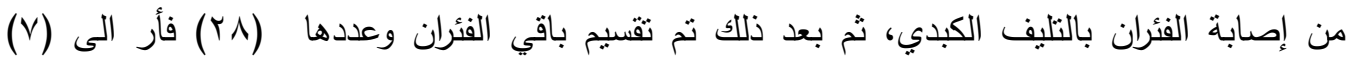

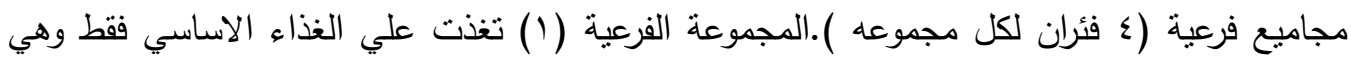

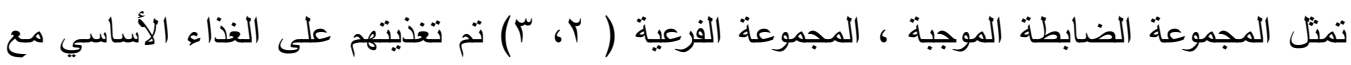
اضافة الزعتر بنسبة 7\% و ا \% على التوالي والمجموعة الفرعية (ع، 0) تم تغذيتهم علي الغذاء

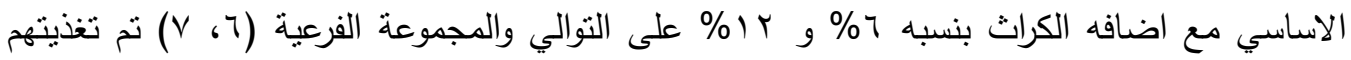

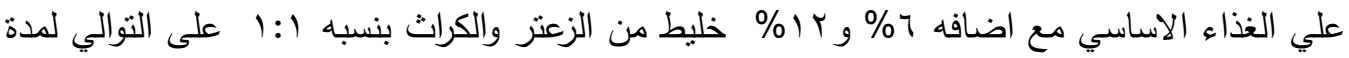

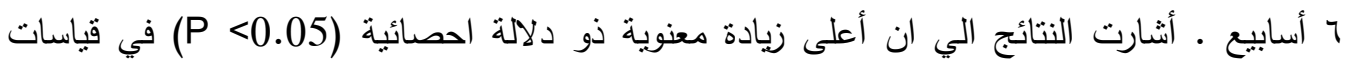

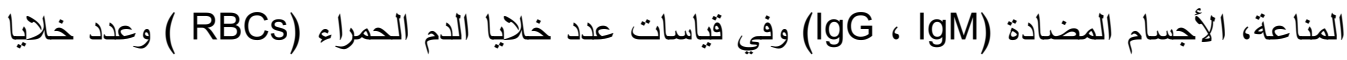
الدم البيضاء (WBCs) و الهيماتوركيت (PCV) ومستوى الهيموجلوبين والبروتين الكلي في الداء ،الجلوبيولين والألبومين لوحظت في المجموعات التي تغذت على مزيج من الزعتر والكراث. أظهرت

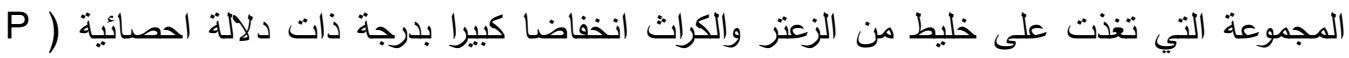
(ALT, AST, ALP) على التوالي مقارنه بالمجموعة الضابطة

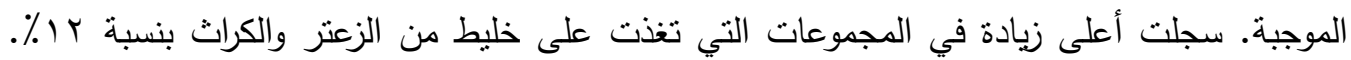

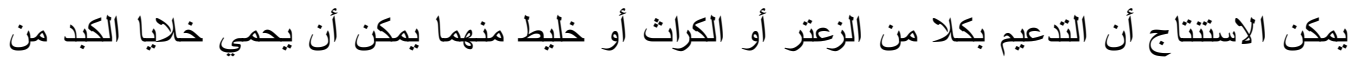

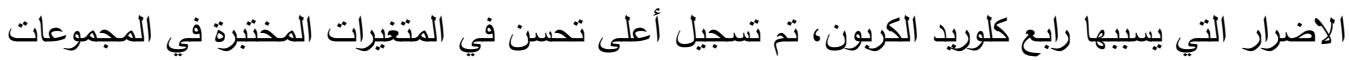
الني تغذت على خليط من الزعتر والكراث. الكلمات المفتاحية: الزعتر -الكراث- الوظائف المناعية- قياسات الدم -تليف الكبد 